number of parietal and goblet cells, EC and EC cells. The reactive changes in exocrinocytes are reflected in the differences in the metric parameters of the external diameter of the gland, the diameter of the lumen, and the height of the epitheliocytes.

Key words: metabolic syndrome, microcirculatory channel, glandular epithelium, mucous membrane.

Надійшла 26.04.2019.

УДК 57.02:599.323:612.82.014.46:616.36-002

doi: 10.25128/2078-2357.19.2.13

О. А. МАКАРЕНКО, Т. В. ГЛАДКІЙ, А. В. МАЙКОВА, Т. В. МОГИЛЕВСЬКА

Одеський національний університет імені I. І. Мечникова

вул. Дворянська, 2, Одеса, Україна, 65082

e-mail: a.maikova@onu.edu.ua

\title{
ПОВЕДІНКОВА АКТИВНІСТЬ ЩУРІВ І РІВЕНЬ ЕНДОТОКСИКОЗУ МОЗКУ НА ТЛІ ГІДРАЗИНОВОГО ГЕПАТИТУ
}

Показано, що формування токсичного гепатиту в щурів шляхом введення їм сірчанокислого гідразину супроводжується гальмуванням орієнтовно-поведінкової, дослідницької та емоційної активності, які відзначаються вже на першому тижні.

На тлі гепатиту в гомогенатах тканин мозку виявляється активність уреази, що свідчить про порушення детоксикаційної функції печінки і можливості розвитку ендотоксикозу мозку Так, у мозку щурів встановлено збільшення активності маркерів запалення, ферментівдеструкторів на тлі зниження активності показників антиоксидантної системи.

Доведено, що зміна поведінкової та емоційної активності щурів на тлі токсичного гепатиту пов'язана з розвитком ендотоксикозу, який є наслідком порушення детоксикаційної функції печінки при гепатиті.

Ключові слова: гідразіновий гепатит, ендотоксикоз, поведінкові реакції, білі щури.

Концепція ендогенної інтоксикації на теперішній час отримала абсолютне визнання у клініцистів, так як саме ендотоксикоз стає основоположним фактором розвитку поліорганної та полісистемної недостатності, які визначають, у переважній більшості випадків, розвиток захворювання [11].

Синдром ендогенної інтоксикації найчастіше супроводжується деструкцією тканин, порушенням обміну речовин, зниженням функціональної активності систем природної детоксикації [7, 10-12].

Розвиток синдрому ендогенної інтоксикації відбувається завжди на тлі порушення роботи печінки, так як при цьому страждає здатність печінки знешкоджувати значну кількість токсичних речовин, що надходять з їжею, а також утворених ендогенним шляхом (наприклад, мікробні метаболіти, аміак, феноли, скатол та ін.) $[4,6,15]$.

Печінкова енцефалопатія $\epsilon$ частим ускладненням i проявом захворювань печінки, $\epsilon$ наслідком печінкової недостатності. При цьому зміни в функціонуванні мозку можуть викликати порушення поведінкових, когнітивних і моторних функцій, зміну особистості, зниження інтелекту [9, 13].

У зв'язку з цим метою роботи було дослідження поведінкової та емоційної активності, а також з'ясування ступеня ендотоксикозу тканин головного мозку щурів на тлі моделювання токсичного хронічного гідразинового гепатиту. 


\section{Матеріал і методи досліджень}

Дослідження проводили на кафедрі фізіології людини і тварин ОНУ імені І. І. Мечникова на 12 лабораторних білих безпородних щурах, самцях, віком 8-10 місяців, масою 300-330 г. Тварини були розділені на 2 групи по 6 особин - контрольну (інтактні тварини) і дослідну (формування моделі токсичного гепатиту).

Формування токсичного гепатиту здійснювали шляхом внутрішньоочеревинного введення сірчанокислого гідразину в дозі 50 мг/кг двічі на тиждень упродовж п'яти тижнів [8].

Про функціональний стан головного мозку щурів по мірі формування гідразинового гепатиту робили висновки на підставі вивчення поведінково-орієнтовної та емоційної активності тварин за методами «Відкрите поле» $\mathrm{i}$ «Т-лабіринт» $[1,3]$.

Поведінково-орієнтовну і емоційну активність щурів перевіряли один раз на тиждень (протягом трьох тижнів) до початку формування гепатиту, а потім протягом періоду формування гепатиту (щотижня протягом 5 тижнів).

Під час перебування тварин у «відкритому полі» (3 хв) реєстрували показники вертикальної, горизонтальної рухової активності, дослідницької та емоційної поведінки [3].

У Т-подібному лабіринті перед твариною ставили завдання просторового розпізнавання при позитивній мотивації - підкріпленні їжею. Враховували час, проведений щуром на стартовому майданчику, кількість зроблених помилок.

Мозок для біохімічних досліджень отримували після виведення тварин з експерименту шляхом евтаназії під тіопенталовим наркозом. Для біохімічних досліджень 75 мг тканини мозку гомогенізували у 1 мл холодного 0,25 M Tris-HCL-буфері, pH 7,4 [8].

У гомогенатах головного мозку визначали активність ряду ферментів, які могли б вказати на причину змін функціонування нервової системи: активність лізоциму, уреази, еластази, каталази, вміст малонового діальдегіду [8].

При проведенні експериментальних досліджень тварини знаходились в стандартних умовах віварію згідно з нормами і принципами Директиви Ради ЕС з питань захисту хребетних тварин, що використовуються для наукових цілей [14]. Висновок комісії Одеського національного університету імені І. І. Мечникова з біоетики, протокол № 3 від 5.09.2019.

Статистичну обробку отриманих даних у серіях дослідів проводили за методом Ст'юдента-Фішера. Достовірними відхиленнями вважали ті, що знаходились в межах вірогідності за таблицями Ст'юдента, $\mathrm{p} \leq 0,05$.

\section{Результати досліджень та їх обговорення}

Рухова активність контрольних тварин, як вертикальна, так і горизонтальна, не розрізнялися на початку досліду. Але вже через тиждень після введення гідразину у щурів дослідної групи 3 моделлю гепатиту спостерігали різке достовірне пригнічення як вертикальної, так i горизонтальної активності. Тобто вертикальна активність знизилася на 52,1\% (p<0,05) в порівнянні $з$ вихідними даними, а горизонтальна - на 29,6\% (p<0,05) (рисунок). Слід відзначити, що зниження рухової активності спостерігалось впродовж п’яти тижнів формування токсичного гепатиту. Такий самий висновок можна зробити про дослідницьку активність: так, на першому тижні вона знижувалась на 43,6 \% (p<0,05), а на п'ятому на 59,7 \% ( $<0,05)$ відносно вихідних даних (рисунок).

Зниження загальної рухливості дослідних тварин в цьому тесті розцінюється як підвищення рівня стресу. Завмирання тварини, їі нерухомість і зменшення грумінгу також можна розглядати як симптом страху. Як видно з рисунка, кількість грумінгів у контрольній групі тварин збільшувалася, а кількість болюсів істотно не змінювалась у порівнянні 3 вихідними значеннями. У дослідної групи вже до кінця першого тижня спостерігали зменшення числа вмивань на $70 \%(\mathrm{p}<0,05)$ у порівнянні з вихідними значеннями, однак при цьому збільшувалась кількість болюсів - на 119\% (p<0,05). 

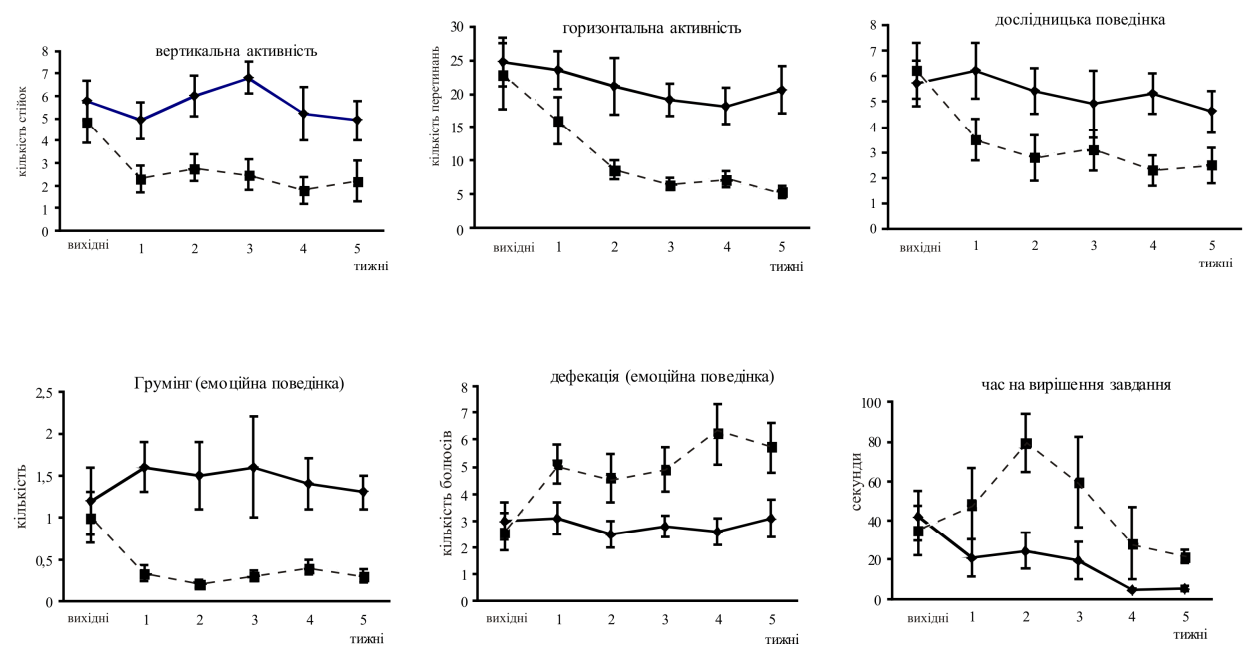

Рисунок. Динаміка рухової, дослідницької, емоційної та когнітивної здібності щурів на тлі формування токсичного гепатиту; суцільна лінія - контроль; штрихова - гепатит

Таким чином нами встановлено, що у щурів, яким моделювали гепатит, спостерігалася зміна поведінкових реакцій, що може бути наслідком змін, які виникають в нервовій системі під впливом ендотоксинів, прохідних через печінковий бар'єр. Здатність до екстраполяції (тобто здатність до вирішення елементарної логічної задачі) є одним 3 найпростіших проявів елементарної розумової діяльності тварин [5].

Як видно з рисунка, на вирішення завдання з вибору потрібного рукава у Т- лабіринті щури контрольної групи витрачали у середньому 40 сек. У наступні періоди спостережень (один раз на тиждень) щури сформували стереотипну реакцію і швидкість виконання завдання зменшилася до 4,7 - 5,5 сек, тобто фактично це був час, що витрачається щуром на пробіжку до потрібного рукава лабіринту. Одночасно зменшувалася кількість допущених помилок при вирішенні задачі в Т-лабіринті.

Щури дослідної групи в перші три тижні розвитку токсичного гепатиту значно погіршили показники, порівняно з вихідними даними. Так, до кінця першого тижня час, витрачений на вирішення завдання, збільшився порівняно з вихідним на $38,8 \%$ (p<0,05), а до кінця другого тижня час збільшився на $126,2 \%$ (р<0,05) (див. рисунок). Отже, у щурів 3 моделлю гепатиту спостерігалося порушення швидкості і якості навчання в Т-подібному лабіринті.

Таким чином на тлі моделювання гідразинового гепатиту спостерігали зміну роботи головного мозку щурів, що проявлялася в порушенні орієнтовно-поведінкової активності, емоційної, пізнавальної діяльності та когнітивних функцій.

На підставі отриманих даних можна припустити, що при розвитку гепатиту певні кількості токсичних речовин надходили в кровотік і досягали тканин мозку. Тому було проведено дослідження активності ферментів мозку щурів, що могло б вказати на причину змін функціонування нервової системи. Результати визначення цих показників наведено в таблиці і вони показують істотні порушення досліджуваних ферментів (таблиця).

На тлі моделювання гепатиту в мозку щурів виявлена уреазна активність, яка в нормі відсутня в цих тканинах. Уреаза не виробляється соматичними клітинами, проте синтезується більшістю умовно-патогенних бактерій (Helicobacter pylori, Proteus mirabilis, Morganella morganii, Providencia rettgeri, Providencia stuartii, Klebsiella pneumoniae, Klebsiella oxytoca, Proteus vulgaris та ін.), які мешкають у товстому кишечнику. У зв'язку з цим уреаза $є$ маркером бактеріальної контамінації. Продуктом діяльності уреази $є$ аміак, який знешкоджується у 
печінці. Тому порушення детоксикаційної функції печінки при гепатиті призводить до потрапляння надмірної кількості як уреази, так і аміаку у кров, що порушує роботу мозку [7].

В тканинах мозку на тлі збільшення маркера бактеріальної контамінації спостерігається зменшення на $22,1 \%$ (p<0,05) активності лізоцима, який можна віднести до маркерів неспецифічного антимікробного захисту. Встановленим зниженням антимікробного захисту можна пояснити підвищення активності уреази (бактеріальної контамінації), а значить й аміаку, що може привести до розвитку ендотоксикозу мозку.

Таблиця

Біохімічні показники головного мозку щурів на тлі гідразинового гепатиту $(\mathrm{M} \pm \mathrm{m})$

\begin{tabular}{|c|c|c|c|c|c|}
\hline Групи & $\begin{array}{c}\text { Активність } \\
\text { уреази, } \\
\text { мккат/кг }\end{array}$ & $\begin{array}{c}\text { Активність } \\
\text { лізоциму, } \\
\text { ед/кг }\end{array}$ & $\begin{array}{c}\text { Активність } \\
\text { каталази, } \\
\text { мкат/кг }\end{array}$ & $\begin{array}{c}\text { Кількість } \\
\text { МДА, } \\
\text { ммоль/кг }\end{array}$ & $\begin{array}{c}\text { Активність } \\
\text { еластази, } \\
\text { мккат/кг }\end{array}$ \\
\hline Контрольна & 0,0 & $86,0 \pm 6,0$ & $2,76 \pm 0,14$ & $70,0 \pm 3,01$ & $20,62 \pm 2,25$ \\
\hline $\begin{array}{c}\text { Дослідна } \\
\text { (гепатит) }\end{array}$ & $8,2 \pm 0,7$ & $67,0 \pm 4,0$ & $1,91 \pm 0,08$ & $85,08 \pm 4,93$ & $29,81 \pm 2,34$ \\
\hline Р & $<0,05$ & $<0,05$ & $<0,05$ & $<0,05$ & $<0,05$ \\
\hline
\end{tabular}

Як видно з даних таблиці, при моделюванні гепатиту в головному мозку щурів спостерігалося достовірне збільшення рівня малонового діальдегіду (МДА) на 21,5\% (p<0,05), що свідчить про активацію перекисного окиснення ліпідів. Накопичення МДА у мозкової тканині щурів з гепатитом $€$ також доказом розвитку ендотоксикозу (таблиця).

В якості маркера антиоксидантної системи досліджували активність каталази. Результати аналізу показують, що у щурів 3 моделлю гепатиту активність каталази достовірно нижча, ніж у контрольній групі на $30,8 \%$ (p<0,05). Це свідчить про ослаблення антиоксидантних захисних систем головного мозку в умовах моделювання гепатиту (таблиця).

У щурів з моделлю гепатиту в мозку виявлено підвищення на $44,6 \%(\mathrm{p}<0,05)$ активності еластази - маркера запалення. Цей фермент бере участь в процесі ушкодження ендотелію капілярних судин і гематоенцефалічного бар'єру, який захищає центральну нервову систему від чужих речовин, що потрапили в кровотік. Тому підвищення еластази може вказувати на нейродеструкцію тканини головного мозку, на ознаки ендотеліальної дисфункції, що супроводжується підвищеною проникністю гематоенцефалічного бар'єру [2].

Відповідно, отримані результати показують, що в головному мозку на тлі розвитку токсичного гепатиту розвивається запальна реакція, що супроводжується послабленням антиоксидантної системи, посиленням перекисного окислення ліпідів і нейродеструктивними процесами.

Отже, у ході дослідження встановили, що у щурів з токсичним гепатитом спостерігається зміна поведінкових реакцій, які можуть бути наслідком накопичення у головному мозку ендотоксинів (аміак, уреаза, МДА), що проходять через пошкоджений при гепатиті печінковий бар'єр. Виявлені порушення відбуваються на тлі зниження антиоксидантного та антимікробного захисту головного мозку щурів з гепатитом. У цілому, зміна поведінкової та емоційної активності щурів з гепатитом пов'язана з розвитком ендотоксикозу, який є наслідком зниження антитоксичної функції печінки при гепатиті.

\section{Висновки}

1. За умов формування хронічного токсичного гепатиту у щурів знижувалась рухова, горизонтальна і вертикальна активність на 50-70\%, дослідницька активність - на 40-60\%, грумінг - до 70\%.

2. У щурів з моделлю гепатиту спостерігалося порушення когнітивних функцій, швидкість навчання була значно гіршою та кількість скоєних помилок була більшою, ніж у інтактної групи тварин. 
3. Моделювання гепатиту у щурів призвело до зниження антимікробного (зменшення активності лізоциму на 22,1\%) та антиоксидантного (падіння активності каталази на $30,8 \%$ ) захисту у головному мозку тварин.

4. При гепатиті в головному мозку щурів спостерігали розвиток запалення (збільшення активності еластази на 44,6\%), накопичення токсинів (збільшення вмісту малонового діальдегіду на 21,5 \%) і виявлення уреазної активності.

1. Амикишиева А. В. Поведенческое фенотипирование: современные методы и оборудование / А. В. Амикишиева // Вестник ВОГиС. - 2009. - Т. 13, № 3. - С. 529-538.

2. Говорин Н. В. Нейромаркеры и показатели эндотелиальной дисфункции при острой шизофрении / Н. В. Говорин, А. И. Васильева // Социальная и клиническая психиатрия. - 2011.- Т. 21, № 1.C. 29-33.

3. Гостюхина А. А. Поведенческая активность крыс в «Открытом поле» после световой или темновой депривациии физического переутомления / А. А. Гостюхина, Т. А. Замощина, М. В. Светлик // Бюллетень сибирской медицины.- 2016.- Т. 15, № 3. - С. 16-23.

4. Гуща В. К. Состояние нейромедиации в некоторых отделах головного мозга крыс при хронической и прерывистой алкогольной интоксикации / В. К. Гуща, С.В.Лелевич // Журнал Гродненского государственного университета. - 2017. - Т. 15, № 5. - С. 521-526.

5. Исакова Л. С. Пространственно-временные паттерны поведения крыс с различной прогностической устойчивостью к стрессу в тесте «открытое поле» / Л. С. Исакова, А. Д. Юдицкий, А. А. Пермяков // Современные научные исследования и инновации. - 2015. - № 1. Ч. 3 [Электронный ресурс]. URL: http://web.snauka.ru/issues/2015/01/41943 (дата обращения: 17.09.2019).

6. Королева М. В. Фармакоэпидемиологическая и клинико-лабораторная характеристика лекарственно-индуцированного поражения печени при туберкулезе / М. В. Королева // Журнал инфектологии. - 2015. - Т. 7, № 14. - С. 44-50.

7. Левицкий А. П. Антимикробная функция печени / А. П. Левицкий, С. А. Демьяненко, Ю. В. Цисельский. - Одеса: КП «Одеська міська друкарня», 2011.- 141 с.

8. Левицкий А. П. Методы экспериментальной стоматологии: Учебное пособие / А. П. Левицкий, О. А. Макаренко, С. А. Демьяненко. - Симферополь: ООО «Изд-во Тарпан», 2018. - 78 с.

9. Лелевич С. В. Нейромедиаторные нарушения в головном мозге при хронической интоксикации алкоголем и морфином в эксперименте / С. В. Лелевич // Весці Нацыянальнай Акадэміі Навук Беларусі. Серыя медыцынскіх навук. - 2011. - № 2. - С. 49-56.

10. Лисицкий Д. С. Основные методы оценки нейротоксических последствий тяжёлой формы острого отравления этанолом / Д. С. Лисицкий, К. О. Войцехович, А. С. Мелехова // Токсикология. - 2015. T. 16. - C. $138-149$.

11. Меркушкина И. В. Коррекция метаболических нарушений головного мозга при эндотоксикозе : автореф. дис. на соиск. ст. док. мед. наук: 14.00.16. / И. В. Меркушкина. - Саранск, 2009 - С. 38.

12. Полунина Т. Е. Лекарственные поражения печени / Т. Е. Полунина // iDoctor. - 2013. - № 5. - С. 23-28.

13. Сытник К. А. Печеночная энцефалопатия при хронических заболеваниях печени: практические рекомендации Европейской ассоциации по изучению печени и Американской ассоциации по изучению заболеваний печени / К. А. Сытник // Сучасна гастроентерологія. - 2015. - № 2 (82). C. $124-135$.

14. European convention for the protection of vertebrale animals used for experimental and other scientific purposes. - Strasburg: Council of Europe, 1986. - № 123. - 51 p.

15. Quigley E. The gut microbiota and the liver. Patophysiological and clinical implications / E. Quigley, C. Stanton, E. Murphy // J. Hepatol. - 2013. - Vol. 58.- P. 1020-1027.

\section{References}

1. Amikishieva A. V. Povedencheskoe fenotipirovanie: sovremennye metody i oborudovanie / A. V. Amikishieva // Vestnik VOGiS. - 2009. - T. 13, N. 3 - S. 529-538.

2. Govorin N. V. Neyromarkery i pokazateli endotelial'noy disfunktsii pri ostroy shizofrenii / N. V. Govorin, A. I. Vasil'eva //Sotsial'naia i klinicheskaia psikhiatriia. - 2011. - T. 21, N. 1. - S. 29-33.

3. Gostiukhina A. A. Povedencheskaia aktivnost' krys v «Otkrytom pole» posle svetovoy ili temnovoy deprivatsiii fizicheskogo pereutomleniia / A. A. Gostiukhina, T. A. Zamoshchina, M. V. Svetlik // Biulleten' sibirskoy meditsiny. - 2016. - T. 15, N. 3 - S. 16-23. 
4. Gushcha V. K. Sostoianie neyromediatsii v nekotorykh otdelakh golovnogo mozga krys pri khronicheskoy i preryvistoy alkogol'noy intoksikatsii / V. K. Gushcha, S. V. Lelevich // Zhurnal Grodnenskogo gosudarstvennogo universiteta. - 2017. - T. 15, N. 5. - S. 521-526.

5. Isakova L. S. Prostranstvenno-vremennye patterny povedeniia krys s razlichnoy prognosticheskoy ustoychivost'iu k stressu v teste «otkrytoe pole»/ L. S. Isakova, A. D. Iuditskiy, A. A. Permiakov // Sovremennye nauchnye issledovaniia i innovatsii. - 2015. - N. 1. Ch. 3 [Elektronnyy resurs]. URL: http://web.snauka.ru/issues/2015/01/41943 (data obrashcheniia: 17.09.2019).

6. Koroleva M. V. Farmakoepidemiologicheskaia i kliniko-laboratornaia kharakteristika lekarstvennoindutsirovannogo porazheniia pecheni pri tuberkuleze / M. V. Koroleva // Zhurnal infektologii. - 2015. T. 7, N. 14. - S. 44-50.

7. Levitskiy A. P. Antimikrobnaia funktsiia pecheni / A. P. Levitskiy, S. A. Dem'ianenko, Iu. V. Tsisel'skiy Odesa: KP «Odes'ka mis'ka drukarnia», 2011. - 141 s.

8. Levitskiy A. P. Metody eksperimental'noy stomatologii / Uchebnoe posobie. /A. P. Levitskiy, O. A. Makarenko, S. A. Dem'ianenko. - Simferopol': OOO «Izd-vo Tarpan», 2018. - 78 s.

9. Lelevich S. V. Neyromediatornye narusheniia v golovnom mozge pri khronicheskoy intoksikatsii alkogolem i morfinom v eksperimente / S. V. Lelevich // Vestsi Natsyianal'nay Akademii Navuk Belarusi. Seryia medytsynskikh navuk. - 2011. -N. 2. - S. 49-56.

10. Lisitskiy D. S.Osnovnye metody otsenki neyrotoksicheskikh posledstviy tiazheloy formy ostrogo otravleniia etanolom / D. S. Lisitskiy, K. O. Voytsekhovich, A. S. Melekhova // Toksikologiia. - 2015. - T. 16. S. $138-149$.

11. Merkushkina I. V. Korrektsiia metabolicheskikh narusheniy golovnogo mozga pri endotoksikoze : avtoref. dis. ... dok. med. nauk: 14.00.16. / I. V. Merkushkina. - Saransk, 2009 - S. 38.

12. Polunina T. E. Lekarstvennye porazheniia pecheni / T. E. Polunina // iDoctor. - 2013. - N. 5. - S. 23 -28.

13. Sytnik K. A. Pechenochnaia entsefalopatiia pri khronicheskikh zabolevaniiakh pecheni. Prakticheskie rekomendatsii Evropeyskoy assotsiatsii po izucheniiu pecheni i Amerikanskoy assotsiatsii po izucheniiu zabolevaniy pecheni / K. A. Sytnik // Suchasna gastroenterologiia. - 2015. - N. 2 (82). - S. 124-135.

14. European convention for the protection of vertebrale animals used for experimental and other scientific purposes. - Strasburg: Council of Europe, 1986. - № 123. - 51 p.

15. Quigley E. The gut microbiota and the liver. Patophysiological and clinical implications / E. Quigley, C. Stanton, E. Murphy // J. Hepatol. - 2013. - Vol. 58. - P. 1020-1027.

O. A. Makarenko, T. V. Hladkyi, A. V. Maikova, T. V. Mohylevska

Odesa Mechnykov National University, Department Of Human And Animal Physiology, Ukraine

BEHAVIOURAL ACTIVITY OF RATS AND THE LEVEL OF BRAIN ENDOTOXICOSIS AT THE BACKGROUND

Hepatic encephalopathy is a frequent complication and manifestation of liver diseases, and a consequence of liver failure.

Our research aims at studying behavioral and emotional activity, as well as identification of the degree of endotoxicosis of brain tissues of rats at the background of modelling in them of toxic chronic hydrazine hepatitis.

The research was carried out at the Department of Human and Animal Physiology of Odessa National Mechnykov University on laboratory male rats, aged 8-10 months. The animals were divided into 2 groups, 6 animals in each, control (intact animals) and experimental (formation of a model of toxic hydrazine hepatitis) ones.

The functional state of the brain of rats was evaluated by studying the behavioral and emotional activities of animals with the methods of "Open field" and "T- shaped labyrinth".

In brain homogenates, the activity of a number of enzymes was determined, which could indicate the cause of changes in the functioning of the nervous system: the activity of lysozyme, urease, elastase, catalase, the content of malondialdehyde.

It was discovered that formation of toxic hepatitis in rats is accompanied by inhibition of orientation and behavioural activity - on 50-70\%, exploratory - on 40-60\% and emotional - on 30\% in "open field" test, considerable aggravation of dynamics of rate and quality of learning problem solving in T-shaped labyrinth. 
Modeling of hepatitis in rats led to the decrease in lysozyme activity by $22.1 \%$, catalase activity by $30.8 \%$, detection of urease activity in the brain, as well as an increase in elastase activity by $44.6 \%$ and malondialdehyde content by $21.5 \%$. B At the background of hepatitis in homogenates of brain tissues urease activity has been detected, activity of inflammation markers and enzymes-destructors increases, with activity of indices of antioxidant brain system decreasing.

Change of behavioural activity of rats at the background of toxic hepatitis is caused by the development of endotoxicosis, which results from impairment of the function of liver detoxification.

Key words: hydrazine hepatitis, endotoxicosis, behavioural reactions, white rats.

Надійшла 03.05.2019. 